\title{
Farklı Kültürlerden Hemşirelik Öğrencilerinin Özürlülüğe Yönelik Görüşleri: Türkiye- Amerika Birleşik Devletleri Örneği
}

\author{
Hamide KÜPELI $\dot{I}^{1}, \quad$ Renginar ÖZTÜRK DÖNMEZ,$\quad$ Ayla BAYIK TEMEL ${ }^{2}$ \\ ${ }^{I}$ Ege Üniversitesi Tıp Fakültesi Hastanesi; İzmir, Türkiye \\ ${ }^{2}$ Ege Üniversitesi Halk Sağlı̆̆ Hemşireliği Anabilim Dalı; İzmir, Türkiye \\ renginarozturk@gmail.com
}

\begin{abstract}
Özet
Tanımlayıcı tipteki bu araştırma, farklı kültürlerden öğrenci hemşirelerin özürlülüğe yönelik görüşlerinin belirlenmesi amaciyla yürütülmüştür. Araştırma örneklemini Türkiye'de bir hemşirelik yüksekokulunda öğrenim gören son sınıf hemşirelik öğrencileri $(n=104)$ ile Amerika Birleşik Devletleri’nde (ABD) bir Hemşirelik Kolejinde öğrenim gören son sınıf hemşirelik öğrencileri $(n=32)$ olușturmuștur. Araștırma verileri anket formu ile toplanmıștır. İstatistiksel değerlendirme sayı yüzde dağılımı ve $x^{2}$ analizi ile yapılmıştır. Araştırmanın yürütülmesi için hemşirelik okullarının yönetiminden yazılı, öğrencilerden sözel izin alınmıştır. Öğrenci hemşirelerin \%76.5'ini Türkiye'deki, \%23.5'ini ABD'deki öğrenciler oluşturmuştur. Türkiye'deki hemşirelik öğrencilerinin tümünün kadın ve Müslüman olduğu, ABD'deki öğrencilerin \%75.0'inin kadın ve \%78.1'inin Hıristiyan olduğu belirlenmiştir. Türkiye'deki (\%94.2) ve ABD'deki (\%93.8) öğrenciler, özürlülüğü en fazla fiziksel özürlülük boyutu olarak algılamaktadırlar. Türkiye'deki hemşirelik öğrencileri kazaları, genetik nedenleri ve akraba evliliklerini en önemli özürlülük nedeni olarak belirtirken, ABD'deki öğrenciler, kazaları, genetik sebepleri, yaşlılık ve kronik hastalıkları en önemli özürlülük nedeni olarak ifade etmişlerdir. Türkiye'deki öğrencilerin özürlülüğe ilişkin bilgileri diğer gruba göre daha yeterli olmasına rağmen, her iki grubun konuya ilişkin duyarlılıkları yeterli düzeyde bulunmamıştır. Her iki kültürlerdeki hemşirelik öğrencilerinin, özürlülük konusunda bilgileri, duyarlılıkları geliştirilmeli ve bakımla ilgili becerileri artırılmalıdır.
\end{abstract}

Anahtar kelimeler: Özürlülük, çok kültürlülük, hemşirelik öğrencisi, görüş

\section{Turkish and American Nursing College Students'Views Toward Disability}

\begin{abstract}
This descriptive study was conducted to determine views of nursing students of different cultures towards disability. The sample was comprised of 104 of senior students who studying a school of nursing in Turkey and, 32 of nursing students who studying a collage of nursing in United States of America (USA). Data was collected by questionnaire form. In evaluation part, percentage and $\mathrm{x}^{2}$ analyses were used. Approval of the Nursing Schools' administration, and verbal informed consent of nursing students were obtained. $76.5 \%$ of nursing students were attented in Turkey, and $23.5 \%$ of them were attented in USA. Nursing Students in Turkey were women and Muslim. $75.0 \%$ of nursing students in USA were women, and $78.1 \%$ were Christian. $94.2 \%$ of students in Turkey and $93.8 \%$ of students in USA percieved to disability as physical disability. As the most important cause of disability, students in Turkey indicated to accidents, genetic causes, cousin
\end{abstract}


marriages, and students in USA indicated to accidents, genetic causes, elderly and chronic diseases. Although nursing student in Turkey than in the other group of students adequate information on disability, sensitivities on the subject of both groups was not enough. Nursing students of both cultures is increased sensitivity, information and skills for caring about disability.

Key words: Disability, multiculturalism, nursing student, view

\section{Giriş}

Toplum, birbirinden farklı fiziksel, psikolojik ve ekonomik özelliklere sahip insanların bir arada yaşama ihtiyacından oluşmaktadır. Karmaşık yapısına rağmen, toplum bütün ihtiyaçlarını karş1layabilecek bir işbölümü içerisinde örgütlenmiştir. Bu örgütlülük içinde, yaşadığı topluma göre "normal insan" addedilen prototipten farklılaşan insanlar, toplumsal hayat şartları açısından dezavantajlı duruma düşebilmektedir. Bu durumun toplumdaki en göze çarpan örneği özürlülüktür. Akademik literatürde insanlık tarihi kadar eski olduğu kabul edilen özürlülük durumu, bütün insanlığa ait bir olgu olarak kabul edilse bile, özürlü kimdir? özürlülük nedir? sorularının tek bir cevab1 bulunmamaktadır (Güngör ve Güneş, 2011; Parashar ve ark., 2008; Şişman, 2012). Literatürde "özürlü” kavramını açıklayan kurumların, tanımlamayı kendi hizmet alanı ve amacına yönelik oluşturduğu görülmektedir. Birleşmiş Milletlere (BM) göre özürlülük ve sakatlık aynı anlamda kullanılmakta olup; "normal bir kişinin kişisel yada sosyal yaşantısında kendi kendisine yapması gereken işleri, bedensel veya ruhsal yeteneklerindeki kalıtımsal yada sonradan olma herhangi bir noksanlık sonucu yapamaması" şeklinde tanımlanmaktadır (Demirarslan, 2004; Dalbay, 2009). Amerika Birleşik Devletleri'ndeki (ABD) özürlülük "bir kişinin sosyal olarak yapması beklenen rollerini ve sorumluluklarını yerine getirmesini engelleyen, sınırlayan bir durumun varlığı olarak" tanımlanmaktadır. Türkiye'de "doğuştan veya sonradan herhangi bir hastalık veya kaza sonucu bedensel, zihinsel, ruhsal, duygusal ve sosyal yetilerini çeşitli derecelerde kaybetmiş, normal yaşamın gereklerine uymayan bir durumun varlığı" şeklinde tanımlanmaktadır (Dalbay, 2009). Genel olarak, özürlülük kavramı ile ilgili tanımlarda "sınırlı olmak" kavramının yer aldığı fark edilmektedir. Özürlülük, tek ve açık tanımı olmayan bir kavram olması nedeniyle istatistiksel veri toplamanın da oldukça güç olduğu bir alan olmakla birlikte, DSÖ verilerine göre, 1970'lerde dünyada \%10 olan özürlü oranının, 2006 yılına gelindiğinde \%15'e yükseldiği belirtilmektedir. ABD'de 2009 yılında özürlülük oranı \%20-30, Türkiye'de 2002 y1lında 12.3'dür (http://www.cdc.gov, Türkiye Özürlüler Araştırması, 2002). Ülkelerde özürlüğün görülme sıklı̆̆ı benzer orandadır.

Özürlü bireye hekim, hemşire, diyetisyen, fizyoterapist, psikolog ve sosyal hizmet uzmanı gibi profesyonellerden oluşan bir sağlık ekibi tarafından işbirliği ve eşgüdüm içinde hizmet sunulmalıdır. Hastalık Kontrol ve Önleme Merkezi (Centers for Disease Control and Prevention [CDC]), hemşirelere özürlü bireye yönelik sağlık hizmetlerinin geliştirilmesinde önemli sorumluluklar düştüğünü belirtmektedir (Köşgeroğlu ve Boğa, 2011). Özürlülügün tanılanmasından, rehabilitasyonuna kadar geçen sürede hemşireler, özürlü bireye hizmet ve bakım sunmak üzere görev üstlenmektedirler (Bilge ve ark., 2005). Hemşire özürlü bireye yönelik sağlık hizmetlerindeki bakım sorumluğunu ve işlevlerini konu ile ilgili bilgi ve becerisini, iletişim ve liderlik becerilerini, otonom davranma, kendine güvenme, eleştirel düşünme ve karar verebilme gibi profesyonellik gerektiren becerilerini kullanır. Hemşirenin özürlülük konusu kapsamında büyüme-gelişme, işlevler, aile ve kriz teorileri, grup süreci, rol teorileri, uyum ve baş etme, öğrenme teorileri ve değişim süreci konularında bilgili olması gereklidir. Bu bilgiler doğrultusunda hemşirelerin, insanlarda özürlülük durumunu değerlendirebilme, bireyin ve ailenin yaşam biçimini değiştirebilme, bağımsızlığı geliştirebilme, özürlülüğe yönelik damgalanmayı ve özürlü ile çalışabilme konularında da yeterlilik geliştirmeleri gerekmektedir. Sözü edilen bilgi ve beceriler özürlü ve ailesinin işlevlerini en üst düzeye çıkarma, öz bakımını geliştirme, komplikasyonlardan veya özrün ilerlemesinden koruma, olumlu baş etme davranışlarını güçlendirme, bakımın ve hizmetlerin sürekliliğini sağlama, optimal yaşam kalitesini savunma, bireyi güçlendirme, 
bakımın ve hizmetlerin sürekliliğini sağlama, optimal yaşam kalitesini savunma, bireyi güçlendirme gibi katkılar sağlamada hemşireye sorumluluk verir (Matziou ve ark., 2009; Seccombe, 2007).

Literatürde, toplumların önemli bir çoğunluğunu oluşturan özürlü bireylere bakım veren meslek gruplarının, özürlülerin sorunlarını saptamada ve çözüm bulmada yetersiz oldukları ifade edilmektedir (Köşgeroğlu ve Boğa, 2011; Lau and Mackenzie, 2006; Matziou ve ark., 2009). Özürlü bireylerin gereksinimlerinin farkında olmayan, sağlık profesyonelleri, özürlü bireyin ihtiyaçlarına cevap veremez ve bakımını istenilen biçimde gerçekleştiremez (Northway, 2003; Şahin ve Akyol, 2010; Chen ve ark., 2002). Yıldırım ve Altıparmak (2008) çalışmalarında, ebe ve hemşirelerin \%64.3'ünün özürlü birey ile iletişim kurmada, \%50'sinin sağlık gereksinimlerini saptamada, \%2.9'unun yönlendirme de güçlük yaşadıklarını saptamışlardır. Aynı zamanda, öğrenci hemşirelerin, hemşirelere göre özürlülüğe yönelik bilgi ve farkındalıklarının daha az olduğu belirtilmektedir (Lau ve Mackenzie, 2006; Matziui ve ark., 2009; Tervo ve Palmer, 2004; Secombee, 2007; Sar1 ve ark., 2010). Öğrenci hemşirelerin özürlülüğe yönelik farkındalıklarının az oluşu ve daha olumsuz tutuma sahip olmaları, henüz mesleğin profesyonel değerlerine sahip olmamaları sebebi ile ailelerinden edindikleri kişisel değerlerine göre tutum sergiledikleri belirtilmektedir (Secombee, 2007; Matziui ve ark., 2009). Bununla birlikte, çalışmalar, hemşirelik eğitiminde özürlülük konusuna az yer verildiğini göstermektedir (Smeltzer ve ark., 2005; 2010). Öğrenci hemşireler, özürlü bireye bakım verdikçe, konu ile ilgili bilgisi arttıkça olumlu tutuma sahip olduğu araştırma sonuçları ortaya koymaktadır (Chen ve ark., 2002; HornerJohnson ve ark., 2002; Thompson ve ark., 2003). Özürlüğe ilişkin farkındalık ve algı oluşturmada; mesleki eğitim ile birlikte yaşanılan toplum ve etnik grubun en önemli etkenler olduğu belirtilmektedir. Toplumların sahip oldukları kültürel inançları, değerleri, hastalık sağlık ve özürlülük kavramalarının şekillenmesinde etkili olmaktadır (Thompson ve ark., 2003; Parashar ve ark., 2008). Bununla birlikte, özürlülerin bakımı ve rehabilitasyonunda önemli görevler üstlenecek hemşirelik öğrencilerinin özürlülüğe yönelik duyarlılıkları, bilgilerinin belirlenmesi ile ilgili çalışmalara ABD ya da Avrupa ülkelerinde sıklıkla rastlanırken, ülkemizde konu ile ilgili araştırmalar sınırlı sayıdadır. Bundan hareketle bu çalışmada, Türkiye'de ve Amerika Birleşik Devletleri'nde öğrenim gören hemşirelik öğrencilerinin özürlülüğe yönelik görüşlerinin belirlenmesi amaçlanmıştır.

\section{Yöntem}

Bu tanımlayıcı çalışmanın evrenini, Türkiye'de bir hemşirelik yüksekokulunda öğrenim gören son sınıf hemşirelik öğrencileri $(\mathrm{N}=110)$ ve $A B D$ 'deki bir hemşirelik kolejinde öğrenim gören son sınıf hemşirelik öğrencileri ( $\mathrm{N}=38)$ oluşturmuştur. Araştırmada örneklemeye gidilmemiş olup, araştırmaya katılmaya gönüllü Türkiye'de öğrenim gören 104 (katılım oranı=\%94.0) ve ABD'de öğrenim gören 32 hemşirelik öğrencisi (katılım oranı =\%84.0) araştırmanın örneklemini oluşturmuştur.

\section{Veri Toplama Araç ve Yöntemleri}

Veriler literatür incelemesi (Çalık, 2004; Baykan, 2000; Horner-Johnson ve ark., 2002; Thompson ve ark., 2003; Tervo ve Palmer, 2004) yapılarak oluşturulan, 14 açık uçlu ve 21 kapalı uçlu olmak üzere toplam 35 soru içeren anket formu ile toplanmıştır. Anket formunun yedi sorusu öğrencilerin sosyo-demografik özelliklerini tanımlamaya yönelik, 20 sorusu özürlülüğün nedenleri, yaygınlığı, önlenmesi ve özürlü bireylerin haklarına ilişkin iken, yedi sorusu hemşirelerin özürlü bireye karşı görev ve sorumlulukları, daha önce özürlü bireye bakım verme deneyimleri, bakım verme isteklerini belirlemeye yöneliktir. ABD'deki veri toplama formu; araştırmacılar tarafindan Türkçe'den İngilizce'ye çevrilmiş olup, Türkçe ve İngilizce'yi iyi derecede bilen, ABD'de yaşayan uzman bir kişinin görüşü alınarak, formun İngilizce haline son şekli verilmiştir Veriler, Türkiye'de araştırmacılar tarafından hemşirelik öğrencileri ile yüz yüze görüşerek toplanmıştır. ABD'nde anket formu, öğrencilerin öğrenim gördüğü okul yöneticisine gönderilmiştir ve yönetici tarafindan formlar öğrencilere dağıtılarak toplanmıştır. ABD'deki veri toplama araçları posta yolu ile araştırmacılara geri gönderilmiştir. Hem Türkiye hem de ABD'deki veriler, ortak bir SPSS (Stastical Package for Social Science) veri tabanına kodlanmıştır 


\section{Araştırmanın Etik Yönü}

Araştırmanın yürütülmesi için Türkiye'deki ve ABD'deki hemşirelik öğrencilerinin öğrenim gördüğü hemşirelik okullarından izin alınmıştır. Anket formları uygulanmadan önce de, öğrencilere araştırmanın amacı açıklanıp sözlü onamları alınmıştır.

\section{Veri Analizi}

Verilerin analizinde, SPSS 11.5 paket program kullanılmıştır. Sosyo-demografik verilerin analizinde sayı -yüzde, karşılaştırmalı verilerin analizinde $x^{2}$ analizi kullanılmıştır.

\section{Bulgular ve Tartışma}

\section{Öğrencilerin sosyodemografik özellikleri}

Araştırma kapsamındaki hemşirelik öğrencilerinin \%76.5'ini Türkiye'deki, \%23.5'ini ABD'deki öğrenciler oluşturmuştur. Türkiye'deki öğrencilerin yaş ortalaması $23 \pm 2.11$ olup, tümü kadın ve Müslümandır. Öğrencilerin \%95.2'si bekârve \%48.1'i en uzun süre şehirde yaşamıştır. ABD'deki öğrencilerin yaş ortalaması $24 \pm 4.56$ olup, \%75.0'i kadın, \%78.1'i Hıristiyan ve \%65.6'sı bekârdır. ABD'deki hemşirelik öğrencilerinin \%90.6's1 en uzun süre şehirde yaşamıştır (Tablo 1). Ülkemizdeki öğrencilerin tamamının Müslüman olmasına karşın, ABD'deki öğrencilerin dini inanışları farklılık göstermektedir. Bu farklılığın, ABD'nin çok farklı etnik gruplardan oluşan bir devlet olması nedeni ile olduğu düşünülmüştür.

Tablo 1. Türkiye ve ABD'deki Hemşirelik Öğrencilerinin Sosyodemografik Özellikleri

\begin{tabular}{|l|c|c|c|c|}
\hline \multirow{2}{*}{ Sosyo-demografik özellikler } & \multicolumn{2}{c|}{ Türkiye } & \multicolumn{2}{c|}{ ABD } \\
\cline { 2 - 5 } & Say1 & $\%$ & Say1 & $\%$ \\
\hline Yaş grubu & 92 & 88.5 & 9 & 28.1 \\
\hline $20-24$ & 12 & 11.5 & 15 & 46.9 \\
\hline $25-29$ & 0 & 0.0 & 8 & 25.0 \\
\hline 30 ve üzeri & \multicolumn{5}{|c|}{$23 \pm 2.11$} & $24 \pm 4.56$ \\
\hline Yaş ortalaması & 104 & 100.0 & 24 & 75 \\
\hline Cinsiyet & 0 & 0.0 & 8 & 25 \\
\hline Kadın & 104 & 100.0 & 3 & 9.4 \\
\hline Erkek & 0 & 0.0 & 25 & 78.1 \\
\hline Dini inanç & 0 & 0.0 & 4 & 12.5 \\
\hline Müslüman & 99 & 95.2 & 21 & 65.6 \\
\hline Hıristiyan & 5 & 4.8 & 7 & 21.9 \\
\hline Diğer (Ateist, Baptist, Believer ) & 0 & 0.0 & 4 & 12.5 \\
\hline Medeni durum & \multicolumn{5}{|c|}{} \\
\hline Bekâr & 36 & 34.6 & 3 & 9.4 \\
\hline Evli & 50 & 48.1 & 29 & 90.6 \\
\hline Boşanmış & 18 & 17.3 & 0 & 0.0 \\
\hline En uzun süre yaşanılan yer & $\mathbf{1 0 4}$ & $\mathbf{1 0 0 . 0}$ & $\mathbf{3 2}$ & $\mathbf{1 0 0 . 0}$ \\
\hline Büyükşehir & Şehir \\
\hline Kasaba- köy & \multicolumn{5}{|l|}{} \\
\hline Toplam
\end{tabular}

Türkiye'deki hemşirelik öğrencilerinin \%28.0'1, ABD'deki öğrencilerin ise \%3.1'i aynı zamanda hemşire olarak çalışmaktadır. Türkiye'de hemşire olarak çalışan öğrencilerin \%25.0'1 1-5 yıldır, 
ABD'deki öğrencilerinin \%3.1'i ise 6-10 yıldır hemşire olarak çalışmakta idi. Çalışma deneyimleri açısından öğrencilerin benzer özellikler taşıdıkları görülmektedir, ancak Türkiye'de daha fazla sayıda öğrencinin hemşire olarak çalıştı̆̆ dikkat çekicidir. Türkiye'de ortaöğretim düzeyinde hemşirelik eğitiminin olması, yükseköğretim döneminde öğrencilerin, hemşire olarak çalışmasına olanak sağlamaktadır.

\section{Öğrencilerin özürlülü̈̆̆̈̈n nedenleri, özürlü bireylerin yaşamış olduğu sorunlar ve özürlüllüğ̈̈n önlenmesine yönelik görüşleri}

Öğrencilere özürlülüğün ne olduğu açık uçlu soru olarak sorulmuştur. Özürlülük, her iki toplumdaki hemşirelik öğrencileri tarafından en fazla oranda (\%94.2 ve \%93.8) kas iskelet sistemi ile ilgili boyutu ile tanımlanmıştır. Literatürde özürlülük tanımın farklı toplumlarda, farklı biçimlerde algılandığı, belirli bir tanımın bulunmadığı söylense de (Dalbay, 2009) her iki kültürdeki öğrenciler için, özürlülük tanımı en fazla fiziksel bozukluk-yetersizlik olarak algılanmaktadır. Türkiye Özürlüler Araştırması (2002) ve Beşer ve ark. (2006)'nın çalışmasına göre, Türkiye'de en fazla kas iskelet sistemi ile ilgili özürlülük görülmekte, bunu görme ile ilgili özürlülük izlemektedir. Türkiye'deki öğrenciler için diğer özürlülük türleri sırası ile "görme" (\%86.7), "işitme" (\%86.7), "mental gerilik ve öğrenme güçlügü̈" (\%85.6), "süreğen hastalık" (\%85.6) ş̧eklinde tanımlanmıştır. ABD’deki öğrencilerin ise, "süreğen hastalık" (\%84.4), "görme" (\%81.3), "işitme" (\%81.3) ve "mental gerilik ve öğrenme güçlüğü" (\%68.8) şeklinde olmuştur. ABD'de yürütülen bir çalışmada (2007), özürlülük türleri; "fiziksel" (\%9.4), "mental" (\%5.8), "duyuşsal" (\%4.3), "öz bakımı yerine getirmede eksiklik" (\%3.0) şeklinde tanımlanmıştır (CDC, 2009). Öğrencilerin vermiş oldukları yanıtlar, ülkelerindeki literatür ile paralellik göstermiştir, bu da öğrencilerin konuya ilişkin bilgilerinin ve duyarlılıklarının olduğunu düşündürmüştür.

Öğrencilere özürlülüğün hangi sebepler sonucu olabileceği sorulduğunda, Türkiye'deki öğrenciler için ilk üç neden, kazalar (\%30.5), genetik nedenler (\%26.5) ve akraba evlilikleri (\% 9.9) olarak ifade edilmiştir. ABD'deki öğrenciler ise kazaları (\%32.4), genetik nedenleri (\% 19.0), kronik hastalıkları ve yaşl1lığı (\%14.3) en önemli özürlülük nedeni olarak ifade etmişlerdir $\left(x^{2}=5.12, \mathrm{p}<0.05\right)$ (Tablo 2$)$. TÜİK (2010) araştırmasına göre; Türkiye'deki özürlülük nedenleri hastalıklar (\%56.8), genetik nedenler (\%15.9), kazalar (\%9.6) ve gebeliğe bağlı sebeplerle (\%3.0) meydana gelmektedir. Türkiye Özürlüler Araştırmasında (2002) da benzer sonuçlar yer almaktadır. Beşer ve ark. (2006), Türkiye'deki özürlülüklerin \%19,8'inin konjenital nedenlere bağlı olduğunu, doğum öncesi sebeplerin de yaklaşık yarısında akraba evliliği, beşte birinde soya çekim öyküsünün bulunduğunu belirtmişlerdir. Morton ve ark. (2002) yapmış olduğu çalışmada, Pakistanlı çocuklarda, Hintli ve Avrupalı çocuklara oranla genetik sebeplerden kaynaklanan özürlülügün diğer gruplara oranla $10 \mathrm{~kat}$ daha fazla görüldügünü belirtmişlerdir. Bu durumun nedeni olarak da, o topluma özgü akraba evliliği gösterilmiştir. Türkiye'de Pakistan'daki gibi doğu kültürü egemendir ve doğu kültüründe hastalık/özürlülüğe neden olan gelenekler ve yaşam biçimleri vardır. Bununla birlikte, ABD'de (2009) artrit, romatizmal hastalıklar ve kardiyovasküler hastalıkların en önemli özürlülük nedeni olduğu ifade edilmektedir (CDC, 2009). Gelişmekte olan ülkelerde özürlülük, doğum öncesi nedenlere bağl1 sebeplerle, gelişmiş ülkelerde ise sonradan oluşan sebeplerle görülmektedir. Toplumlar arasında var olan kültürel farklılık burada kendini göstermiş ve ABD'ndeki öğrenciler tarafından, Türkiye'deki öğrenciler için çok önemli bir neden olan akraba evliliğinden söz edilmemiştir. Her iki toplumdaki öğrenciler, ülkelerindeki özürlülük nedenlerine ilişkin verdikleri cevaplar ülkelerdeki özürlülük nedenlerini yansıtmıştır.

Tablo 2. Türkiye ve ABD'deki Hemşirelik Öğrencilerine Göre Ülkelerindeki Özürlülük Nedenlerinin Dă̆llımı

\begin{tabular}{|l|c|c|c|c|}
\hline \multirow{2}{*}{ Öğrencilere Göre Özürlülük Nedenleri } & \multicolumn{2}{|c|}{ Türkiye } & \multicolumn{2}{|c|}{ ABD } \\
\cline { 2 - 6 } & Say1 & $\%$ & Say1 & $\%$ \\
\hline Kazalar & 92 & $\mathbf{3 0 . 5}$ & 34 & $\mathbf{3 2 . 4}$ \\
\hline Genetik bozukluklar & 80 & $\mathbf{2 6 . 5}$ & 20 & $\mathbf{1 9 . 0}$ \\
\hline Akraba evlilikleri & 30 & $\mathbf{9 . 9}$ & 0 & 0.0 \\
\hline
\end{tabular}




\begin{tabular}{|l|c|c|c|c|}
\hline Gebelikte yaşanan sorunlar & 20 & 6.6 & 9 & 8.6 \\
\hline Kronik hastalıklar ve yaşlılık & 19 & 6.4 & 15 & $\mathbf{1 4 . 3}$ \\
\hline Doğum eyleminden kaynaklanan sorunlar & 17 & 5.7 & 0 & 0.0 \\
\hline Sigara, alkol, uyuşturucu gibi madde kullanımı & 6 & 1.9 & 3 & 2.9 \\
\hline Bulaşıcı hastalıklar ve bağışılklama eksiklikleri & 6 & 1.9 & 14 & 13.3 \\
\hline Yanlış tedavi uygulamaları & 4 & 1.3 & 0 & 0.0 \\
\hline Diğer & 28 & 9.3 & 10 & 9.5 \\
\hline Toplam & $\mathbf{3 0 2}^{*}$ & $\mathbf{1 0 0 . 0}^{*}$ & $\mathbf{1 0 5}^{*}$ & $\mathbf{1 0 0 . 0}$ \\
\hline
\end{tabular}

*Birden fazla cevap verilmiştir.

Türkiye'de hemşirelik öğrencilerinin \%89.4'ünün, ABD'deki öğrencilerin ise tamamının toplumlarındaki özürlülük prevelansına ilişkin bilgisinin yetersiz olduğu saptanmıştır. Konu ile ilgili yürütülen diğer çalışmalarda da, hemşire öğrencilerin özürlülüğe yönelik bilgilerinin yetersiz olduğu ifade edilmiştir (Seccombe ve ark. 2007; Matziou ve ark., 2009; Smeltzer ve ark. 2010). Öğrencilere, toplumlarındaki özürlü bireye sağlanan hizmetlerin yeterliliği sorulduğunda ise; Türkiye'deki öğrencilerin \%75.0'i özürlü bireylere sunulan hizmetlerin "yetersiz" bulduklarını belirtmişlerdir. TÜİK (2010) tarafından yürütülen çalışmada özürlü bireylerin \%66.9'u kaldırım-yaya geçitlerinin, \% 66.3'ü oturdukları binada hareket etme olanaklarının, \%58.4'ü kamu binalarının fiziki koşullarının kendileri için uygun olmadıklarını belirtmişlerdir. ABD'deki öğrencilerin ise \%78.1'i sunulan hizmeti "yeterli" bulduklarını ifade etmişlerdir. Batı toplumunda yapılan bir çalışmada özürlü bireylerin \%61.0'inin kamu binalarının özürlüler için uygun olmadığı ifade edilmiştir (National Disability Authority [NDA], 2006). Her iki toplumda özürlü bireye yönelik sunulan hizmete ilişkin farklı görüş bulunmuş olmalarına rağmen $\left(x^{2}=3.81, \mathrm{p}<0.05\right)$, kendi toplumlarındaki özürlü bireylere yönelik sunulan hizmetlerinin yeterliliğini doğru değerlendirdikleri söylenebilir.

Hemşirelik öğrencilerine özürlülüğün önlenmesine yönelik görüşleri sorulduğunda; Türkiye'deki öğrencilerin \%60.1'inin, ABD'deki öğrencilerin \%85.7'sinin bu soruyu cevaplamadığı belirlenmiştir. Smeltzer ve ark. yürüttükleri çalışmalarda da öğrencilerin özürlülük ile ilgili soruları yanıtlama oranlarını \%23.4 ve \%33.3 olarak elde ettiklerini ifade etmişlerdir (Smeltzer ve ark. 2005; 2014). Bununla birlikte, Parashar ve ark. (2008) özürlülüğe ilişkin çalışmaların en fazla ABD'de yürütüldüğünü belirtmelerine rağmen, $\mathrm{ABD}$ 'deki hemşirelik öğrencilerinin bu soruya az oranda cevap vermesi dikkat çekicidir. Soruyu yantlayan, Türkiye'deki öğrencilerin \%34.5'i doğum öncesi danışmanlık ve izlemin, \%23.1'i eğitimin, \%12.8'i kazaların önlenmesinin, \%11.6's1 akraba evliliklerinin engellenmesinin ve \%3.6's1 sağlı hizmetlerinde bakım kalitesinin artırılmasının özürlülüğü önleyeceği görüşündedirler. ABD'deki hemşirelik öğrencilerin \% 26.6's1 kazaların engellenmesine yönelik politika oluşturmanın, \%26.6's1 rutin sağlık kontrollerinin yapılmasının, \%20.0'si sağlık hizmetlerinde bakım kalitesinin artırılmasının, \%13.4'ü tedavi hatalarının engellenmesinin, \%6.7'si fizik tedavi ve rehabilitasyon hizmetlerinin, \%6.7'si iş yerinde korunma önlemleri alınmasının özürlülüğü önleyeceği görüşündedir (Tablo 3).

Tablo 3. Türkiye ve ABD'deki Hemşirelik Öğrencilerinin Özürlülügün Önlenmesine Yönelik Görüssleri

\begin{tabular}{|c|c|c|c|c|}
\hline \multirow{2}{*}{ Özürlülüğün Önlenmesine Yönelik Görüşler } & \multicolumn{2}{|c|}{ Türkiye } & \multicolumn{2}{|c|}{ ABD } \\
\hline & Say1 & $\%$ & Say1 & $\%$ \\
\hline Doğum öncesi danışmanlık ve izlem & 57 & 34.5 & 0 & 0.0 \\
\hline Özürlü & 38 & 23.1 & 0 & 0.0 \\
\hline Kazaları & 21 & 12.8 & 4 & 26.6 \\
\hline Akraba evliliklerin & 19 & 11.6 & 0 & 0.0 \\
\hline Sağlık hi & 6 & 3.6 & 3 & 20.0 \\
\hline Erken tanı hizm & 5 & 3.1 & 0 & 0.0 \\
\hline Doğumlar güvenli biçimde gerçekleştirilmeli & 5 & 3.2 & 0 & 0.0 \\
\hline Radyasyondan kaçınılmalı & 4 & 2.0 & 0 & 0.0 \\
\hline Rehabil & 4 & 2.4 & 1 & 6.7 \\
\hline Bağışıklama hizmetleri tam olarak sağlanma & 3 & 1.9 & 0 & 0.0 \\
\hline
\end{tabular}



TÜRKIYE- AMERIKA BIRLEŞIK DEVLETLERI ÖRNEĞI

\begin{tabular}{|l|c|c|c|c|}
\hline Tedavi ve bakım hataları engellenmeli & 3 & 1.8 & 2 & 13.4 \\
\hline İş yerinde korunma önlemleri alınmalı & 0 & 0.0 & 1 & 6.7 \\
\hline Rutin sağlık kontrolleri yapıllmalı & 0 & 0.0 & 4 & 26.6 \\
\hline Toplam & $\mathbf{1 6 5}^{*}$ & $\mathbf{1 0 0 . 0}$ & $\mathbf{1 5}^{*}$ & $\mathbf{1 0 0 . 0}$ \\
\hline
\end{tabular}

* Birden fazla yanıt verilmiştir

Türkiye'deki ve ABD'deki öğrencilerin özürlülüğün önlenmesine yönelik görüşleri farkl1lık göstermektedir. Türkiye'deki öğrenciler daha çok doğum öncesi nedenlere ve eğitime vurgu yaparken, ABD'deki öğrenciler daha çok politika oluşturma ve kronik hastalıklara yönelik rutin sağllk izlemine vurgu yapmışlardır. Aynı zamanda, her iki grupta da özürlülügün önlenmesine yönelik verilen cevapların tümüne yakını sağlı hizmetlerine yönelik olmuştur. Bu bulgu, mesleki eğitim sonucu kazanılan farkındalığın daha çok sağlık boyutunda olduğunu düşündürmüştür. Öğrencilerin özürlük nedenleri ile özürlülüğün önlenmesine yönelik görüşleri birbiri ile örtüşmektedir. Hemşire öğrenciler toplumlarında özürlülüğe neden olan durumların, özürlülüğün önlenmesinde etkili olduğu görüşündedirler. Türkiye'deki öğrenciler özürlülüğün en fazla oranda genetik nedenler ve akraba evliliği sonucu olacağı görüşündedirler ve özürlülüğü önleme olarak da doğum öncesi danışmanlık ve eğitimin gerekliliğini ifade etmişlerdir. ABD'deki hemşire öğrenciler ise, bireysel önlemlerden ziyade, politika oluşturma ve rutin sağllk hizmetleri alma gibi genel ve toplumsal önlemlere vurgu yapmışlardır. Öğrencilerin özürlülüğün önlenmesine yönelik toplumlarının sosyokültürel özelliklerine bağlı olarak soruyu cevapladıkları belirlenmiştir.

Hemşirelik öğrencilerine özürlü bireylerin yaşadığı sorunlar açık uçlu soru olarak sorulmuştur. Türkiye'deki hemşirelik öğrencilerinin \%36's1, ABD’ndeki öğrencilerin \%61'i soruya cevap vermemiştir. Smeltzer ve ark. yürüttükleri çalışmalarda, benzer biçimde düşük oranlarlarda yanıtlama olduğundan söz etmektedirler (Smeltzer ve ark. 2005; 2010). Soruyu cevaplayan, Türkiye'deki hemşirelik öğrencilerin $\% 22.5^{\prime} \mathrm{i}$ özürlü bireylerin ulaşım, \%17.9'u iş bulamama, \%16.4'ü eğitim, \%16.4'ü damgalanma, \%14.9'u sosyal faaliyetlerden yoksunluk ve \%11.9'u bağımlı olma sorunu yaşadıklarını düşünmektedirler. ABD'ndeki öğrencilerin \%28.2'sinin benlik saygısında azalma, \%20.4'ünün bağımlı olma, \%15.4'ünün ulaşım, \%15.4'ünün sosyal faaliyetlerden yoksunluk, \%10.3'ünün iş bulamama ve \%10.3'ünün damgalanma sorunu yaşadıkları görüşündedirler (Grafik 1). “Türkiye Özürlüler Araştırması'na (2002) göre, Türkiye'de özürlü bireylerin karşılaştığı sorunlar; devletin sağladığı imkânların yetersiz olması, kamuya açık alanlarda sesli uyarı işaretleri ve düzenlemelerin yeterli olmaması, toplu taşım araçlarına binmekte zorluk çekme ve evlilik yaşamının olumsuz etkilenmesi olarak sıralanmıştır. Türkiye'deki öğrencilerin, özürlülerin en çok karşılaştıkları sorunları ulaşım, iş, eğitim sorunları ve toplumun olumsuz bakış açısı olarak değerlendirmeleri, Türkiye Özürlüler Araştırması (2002) ile uyuşmaktadır. Son yıllarda Türkiye'nin Avrupa Birliği'ne üye devlet olma için adaylık sürecinde olması ile özürlülük konusunda sosyal içerme, sosyal dışlanma gibi kavramlar sıklıkla kullanılır olmuştur (Dalbay, 2009). Öğrencilerin de ülkelerindeki sosyal gündemin farkında oldukları ve bu farkındalığın görüşlerine de yansıdığı söylenebilinir. ABD'deki öğrenciler için özürlü bireylerin en önemli sorunları bağımlılık, ulaşım, eşitsizlik ve kişinin benlik saygısında azalma olarak ifade edilmiştir. Türkiye'deki öğrencilerin algıları daha çok iş bulamama, eğitim sorunları gibi gelişmekte olan ülkelerin toplumsal sorunlarını yansıtırken, ABD'deki öğrenciler tarafından bu gibi sorunlar dile getirilmemiştir. Toplumlar arasındaki, işsizlik oranları incelendiğinde Türkiye'de özürlü bireylerin işsizlik oranı \%66.4 iken, ABD'de bu oran \%16.1'dir. Türkiye'de özürlü nüfus içinde işgücüne katılım oranı \%2.7 iken, ABD'de bu oran \%19.5'dir (TÜIK, 2010; http://www.dol.gov.). Özürlü bireylerin işsizlik oranı ile işgücüne katılım oranları arasındaki fark, her iki gruptaki öğrencilerin görüşleri arasındaki farklılığı yansıtmaktadır. Türkiye Özürlüler Araştırmasında (2002) özürlü bireylerin sorunlarından birinin de evlilik olduğu belirtilmiştir. Türkiye'deki öğrencilerin \%86.5'i, ABD'li katılan öğrencilerin tamamı özürlülerin evlenme hakk1 olduğunu düşünmektedir. Chen ve ark. (2002) yürüttükleri araştırmada, ABD’li öğrencilerin Singapur ve Tayvan'lı öğrencilere göre, özürlülerin evlenmesi gerektiğine ilişkin daha olumlu tutumları olduğu belirtilmiştir. Aynı çalışmada batı toplumlarında, özürlülere yönelik tutumun diğer toplumlara göre daha olumlu olduğundan söz etmişlerdir ki, çalışmada da benzer bir sonuç ortaya çıkmıştır. 


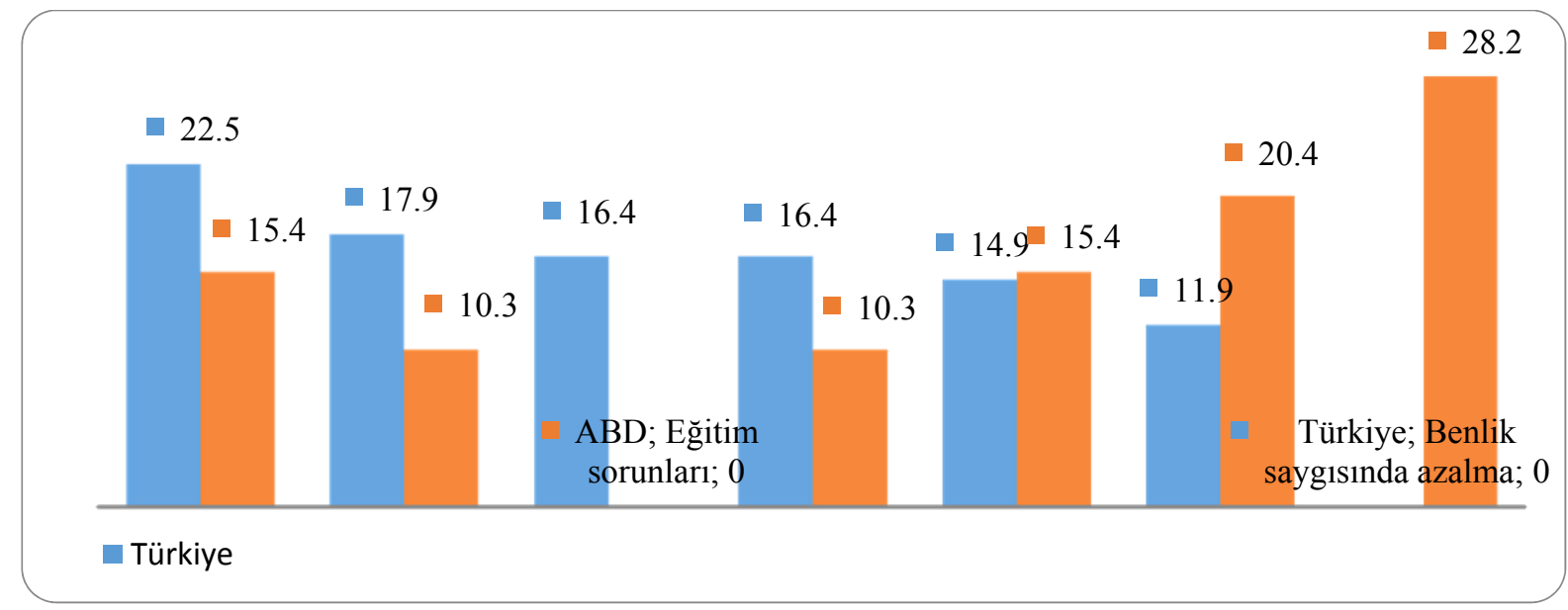

Grafik 1. Hemşirelik Öğrencilerinin Baklş Açısı ile Ülkelerindeki Özürlü Bireylerin Yaşadı̆̆ Sorunların Dağılımı

\section{Öğrencilerin özürlü bireye yönelik hemşirelik uygulamalarına yönelik görüssleri}

Hemşirelik öğrencilerine özürlü bireye yönelik hemşirenin görevlerinin neler olduğu sorulmuştur. Türkiye'deki hemşirelik öğrencilerinin \%51.8'i eğitim, \%26.9'u koruyucu sağlık hizmetleri sunma ve $\% 15.9$ 'u genetik danışmanlık yapması gerektiğini ifade etmişlerdir. ABD'deki öğrenci hemşirelerin, \%43.0'ü eğitim, \%21.4'ü koruyucu sağlı hizmetleri sunma ve yanlış uygulamalardan kaçınma, \%7.1'i rehabilitasyon hizmetleri sunma olduğunu belirtmişlerdir (Grafik 2). Her iki toplumdaki öğrenciler, hemşirenin görevine ilişkin olarak en fazla eğitime vurgu yapmışlardır. Özür durumunun oluşmasında en önemli unsur, riskten kaçınmadır. Özürlülüğe neden olan etmenleri, riskleri engellemede en etkili faktör eğitimdir. Köşgeroğlu ve Boğa (2011) hemşirelerin; özürlü bireylere yönelik kazalardan korunma eğitimi (\%60), sağlık kontrolleri (\%58.6), beslenme eğitimi (\%58.6), bağışıklama (\%57.1), büyüme gelişme izlemi (\%55.7), tuvalet eğitimi (\%51.4), öz bakım eğitimi (\%47.1), aile danışmanlığ (\%45.7) ve genetik danışmanlık (\%30.0) gibi koruyucu sağlık hizmetleri görevlerini yaptıklarını saptamışlardır. Öğrencilerin hemşirenin görevlerine ilişkin görüşleri, literatür bilgisi ile uyuşmaktadır.

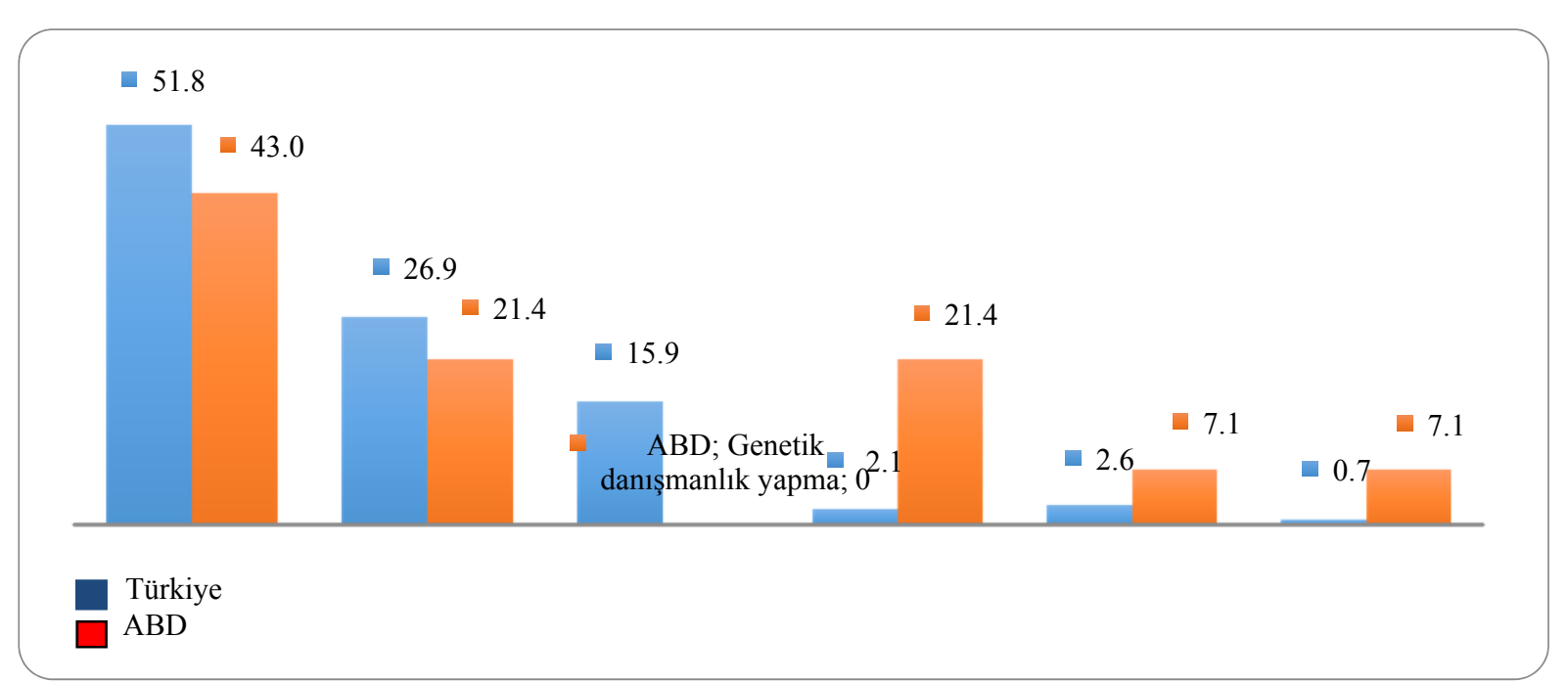

Grafik 2. Özürlü Bireye Yönelik Hemşirenin Görevlerinin Neler Olması Gerektiğine İlişkin Öğrencileri Görüşleri 
Türkiye'deki hemşirelik öğrencileri arasında öğrenimleri süresince özürlü bireye bakım verme oranı \%58.7, ABD'deki hemşirelik öğrencilerinin öğrenimleri süresince özürlü bireye bakım verme oran1 \%59.4'dur. Türkiye'de hemşirelik öğrencilerinin özürlü bireye bakım verirken \%82.2'sinin "çok-orta" derecede doyum aldığı, \%17.8'inin "az-hiç" doyum almadığı belirlenmiştir. ABD'de hemşirelik öğrencilerinin özürlü bireye bakım verirken \%89.5'inin "çok-orta" derecede doyum aldığı, \%10.5'inin "az-hiç" doyum almadığ 1 belirlenmiştir. Her iki kültürdeki hemşirelik öğrencilerinin, özürlü bireye bakım verme ve bakım verirken doyum alma durumlarının benzer olduğu saptanmıştır $\left(x^{2}=1.21, \mathrm{p}>0.05\right)$. Konu ile ilgili yapılmış pek çok çalışmada, hemşirelik öğrencilerinin konu ile ilgili dersler aldıktan sonra özürlülere yönelik olumlu tutumlarının anlamlı derecede arttı̆̆ 1 belirtilmiştir. Aynı zamanda, özürlülere bakım veren öğrencilerin bakım vermeyen öğrencilere göre özürlülere karşı tutumlarının daha olumlu olduğu ifade edilmektedir (Tervo, 2004; Lau ve ark., 2006; Seccombe, 2007; Parashar ve ark., 2008; Matziou ve ark., 2009; Sarı ve ark., 2010). Çalışmada, her iki kültürdeki öğrencilerin yarısından fazlasının özürlü bireye bakım vermesinin, özürlü bireye yaklaşım açısından olumlu olacağ 1 düşünülmektedir.

\section{Sonuç ve Öneriler}

Türkiye'deki hemşirelik öğrencilerinin sorulara verdikleri yanıtların oranı, ABD'deki öğrencilerden daha fazla olmasına rağmen, yine de her iki grubun soruları yanıtlama oranlarını yetersiz bulunmuştur. Özürlülük nedenlerini tanımlamalarında ve özürlülere yönelik verilen hizmetleri yeterli bulma düzeyleri arasında her iki grup arasında farklılığın olduğu ve kendi toplumlarındaki durumu yansıttıkları fark edilmiştir. Öğrencilerin özürlü bireylere bakım verme ve bakımdan duydukları memnuniyet durumu arasında fark olmadığı, hemşirenin görevlerine ilişkin olarak birincil koruma önlemlerine vurgu yaptıkları belirlenmiştir. Her iki gruptaki öğrencilerin özürlülük konusunda bilgi ve duyarlılıkları geliştirilmeli, uygulama alanlarında özürlü bireylere bakım verme olanakları artırılmalıdır. Hemşirelik müfredat programlarında özürlülük ile ilgili konular genişletilmelidir.

\section{Kaynaklar}

1. Baykan, Z. 2000. Özürlülük, Engellilik, Sakatlık Nedenleri ve Korunma. http://www.ttb.org.tr/STED/ sted0900/4.html (erişim tarihi:01.04.2014).

2. Beşer, E., Atasoyluğu, G., Akgör, Ş., Ergin F., Çullu E. 2006. Aydın il merkezinde özürlülük prevalansı, etyolojisi ve sosyal boyutu. TSK Koruyucu Hekimlik Bülteni, 5, 267-275.

3. Bilge, A., Genç. R., Nişli, İ. 2005. Toplumsal bir sorun: engellilik ve hemşirelik yaklaşımı. Ege Üniversitesi Hemşirelik Yüksekokulu Dergisi,21, 181-190.

4. Centers for Disease Control and Prevention (CDC) 2009. Prevalence and most common causes of disability among adults United States. Morbilitiy Mortality. Weekly Report, 58(16), 421-426.

5. Chen, R.K., Brodwin, M.G., Cardosa, E, Chan, F.. 2002. Attitudes toward people with disablities in the social context of dating and marriage: a comparison of American Taiwanese and Singaporean collage students attitudes toward disability. Journal of Rehabilition,68(4),5-11.

6. CCalık, S. 2004. Özürlülüğ̈̈n ölçülmesinde metodolojik yaklaşımlar ve 2002 Türkiye özürlüler araştırması. Öz-Veri Dergisi, 1(2), 303-331.

7. Dalbay, S.R. 2009. Özürlü Yakınlarının Özürlülere Yönelik Sosyal Politikalara İlişkin Bilgi, Beklenti ve Memnuniyet Dereceleri (Isparta Örneği). Yüksek Lisans Tezi, Süleyman Demirel Üniversitesi

8. Demirarslan, S. 2004. Disabled persons and their position at the construction education. The Turkish Online Journal of Educational Technology,3(2)2, 8-15.

9. Disability Employment Policy Resources by Topic. http://www.dol.gov/odep/ (erişim tarihi:15.06.2014).

10. Disability Statistics. http://www.ilr.cornell.edu/edi/DisabilityStatistics/faq.cfm?n=1 (erişim tarihi:01.04.2014).

11. Güngör, F., Güneş, G. 2011. Dünya'daki gelişmeler paralelinde Türkiye'de değisşen özürlülük politikaları. Yalova Sosyal Bilimler Dergisi,3, 25-44.

12. Health, United States, 2007. http://www.cdc.gov/nchs/data/hus/hus07.pdf_(erişim tarihi:15.06.2013). 
13. Horner-Johnson, W., Keys, C., Henry. D., Yamaki, K., Oi, F., Watanabi, K. 2002. Attitudes of Japanese students toward people with intellectual disability. Journal of Intellectual Disability Research,46,365-378.

14. Köşgeroğlu, N., Boğa, S. M. 2011. Yaşam aktivitelerine dayalı hemşirelik modeline göre zihinsel engelli bireylerin sorunları ve hemşirelik. Marmara Üniversitesi Hemşirelik Bilim ve Sanat Dergisi, 4(1), 148-154.

15. Lau, V .M., Mackenzie, A. 1996. Attributes of nurses that determine the quality of care for mentally handicapped people in an institution. Journal of Advanced Nursing, 24, 1109-1115.

16. Matziou, V., Tsoumakas, C., Perdikaris, P. 2009. Attitudes of nurse professionals and nursing students towards children with disabilities. Do nurses really overcome children's physical and mental handicaps? International Nursing Review,56,456-460.

17. Morton, R., Sharma, V., Nicholson J., et al. 2002. Disability in children from different ethnic populations. Health \& Development, 28(1), 87-93.

18. National Disability Authority (NDA). Public Attitudes to Disability in Ireland 2006. http://www.nda.ie/ website/nda/cntmgmtnew.nsf/0/FD9B9DBF1F1CF617802573B8005DDED5?OpenDocument (erişim tarihi: 18.04.2013).

19. Northway, R. 2003. Disability, nursing research and the importance of reflexivity. Journal of Advanced Nursing,32, 391-397.

20. Örsal, Ö. 2008. Hemşirelik Perspektifinden Özürlülük. http://www.ozida.gov.tr/?menu=ozveri\&sayfa= ov8/ov8mak5 (erişim tarihi:15.06.2014).

21. Parashar, D., Chan, F., Leirer, S. 2008. Factors influencing Asian Indian graduate students' attitudes toward people with disabilities a conjoint analysis. Rehabilitation Counseling Bulletin, 51(4), 229-239.

22. Sarı, H.Y., Bektaş, M., Altıparmak, S. 2010. Hemşirelik öğrencilerinin engellilere yönelik tutumlarının belirlenmesi. Yeni Tip Dergisi,27, 80-83.

23. Seccombe, J.A. 2007. Attitudes towards disability in an undergraduate nursing curriculum: a literature review. Nurse Education Today, 27,459-465.

24. Smeltzer S.C., Blunt E., Marozsan H., Wetzel-Effinger L. 2014. Inclusion of disability-related content in nurse practitioner curricula. Journal of the American Association of Nurse Practitioners, http://onlinelibrary.wiley.com/doi/10.1002/2327-6924.12140/pdf (erişim tarihi:15.08.2014).

25. Smeltzer, S.C., Robinson-Smith, F., Dolen, M. A., Duffin, J. \& Al-Maqbali, M. 2010. Disability-related content in nursing textbooks. Nursing Education Perspectives, 31(3), 148-155.

26. Smeltzer, S.C., Dolen, M. A., Robinson-Smith, G. \& Zimmerman, V. 2005. Integration of disability-related content in nursing curricula. Nursing Education Perspectives, 26(4), 210-216.

27. Şahin, H., Akyol. A.D. 2010. Evaluation of nursing and medical students' attitudes towards people with disabilities. Journal of Clinical Nursing, 19 (15-16), 2271-2279.

28. Şişman, Y. 2012. Özürlülük alanında kullanılan kavramlar üzerine genel bir değerlendirme. Sosyal Politika Çalışmaları, 12(7), 28, 70-85.

29. Tervo, R. C., Palmer, G. 2004. Health professional student attitudes towards people with disability. Clinical Rehabilitation, 18, 908-905.

30. Thompson, T.L., Emrich, K., Moore. G. 2003. The effect of cirriculum on the attitudes of nursing students toward disabilty. Rehabilitation Nursing, 28, 27-30.

31. Türkiye Engelliler Araştırması Temel Göstergeleri, 2006. http://www.eyh.gov.tr/tr/8245/TurkiyeEngelliler-arastirmasi-temel-Gostergeleriłoran (erişim tarihi:18.04.2013).

32. Türkiye İstatistik Kurumu (TÜIK), Özürlülerin Sorun ve Beklentileri Araştırması, 2010. http://www.eyh.gov.tr/ upload/Node/8703/files/ozurlulerinsorunvebeklentilerarastirmasi2010pdf (erişim tarihi:18.04.2013).

33. Türkiye Özürlüler Araştırması, 2002. http://www.ozida.gov.tr/arastirma/trozurluaras/ turkce/index_tr.html (erişim tarihi:15.06.2014).

34. Yildırım, H.Y., Altıparmak, S. 2008. The knowledge of nurses and midwives related to mentallyhandicapped children. TAF Prev Med Bull.,7(2), 127-132. 